\title{
СТАН ЗГОРТАЛЬНОЇ СИСТЕМИ ПЛАЗМИ КРОВІ ПРИ НЕОПЛАСТИЧНІЙ ІНТОКСИКАЦІї НА ФОНІ ЕКСПЕРИМЕНТАЛЬНОГО ФЛЕБОТРОМБОЗУ
}

\author{
ФП. Я. Боднар, І. М. Кліщ, Я. Я. Боднар, Т. В. Боднар, Ю. В. Сорока \\ Тернопільський національний медичний університет імені І. Я. Горбачевського МОЗ України
}

РЕзЮМЕ. Погіршення реологічних властивостей крові значно впливає на утворення тромбів та розвиток гіпоксії тканин. Найчастіше клінічно наявні порушення саме на кінцевому етапі фібрино- та тромбіногенезу. Прикладами можуть бути ДВЗ-синдром, ішемічна хвороба серця, інфаркт міокарда, інсульт головного мозку, тромбоз глибоких вен та тромбоемболія легеневої артерії (ТЕЛА). Вивчення механізмів флеботромбозу при неопластичній інтоксикації дозволить запобігати ускладненням та покращить лікування багатьох видів патологій.

Мета - вивчення стану та морфофункціональних змін згортальної системи плазми крові щурів при моделюванні неопластичної інтоксикації на фоні експериментального флеботромбозу з подальшим проведенням статистичного аналізу для запобігання негативним змінам у системі гемостазу.

Матеріал і методи. Експеримент виконано на 25 статевозрілих нелінійних щурах. Хронічну неопластичну інтоксикацію моделювали шляхом введення несиметричного 1,2-диметилгідразин гідрохлориду (ДМг) підшкірно в міжлопаткову ділянку в дозі 7,2 мг/кг 1 раз на тиждень упродовж 30 тижнів, відповідно до маси тварини - 3 розрахунку 0,1 мл розчину ДМГ на 10 г маси тіла щура. Тромбоз глибоких вен тазової кінцівки моделювали за методом S. Wessler і співавт. (1959): поєднання венозного застою (лігування вени) і гіперкоагуляції за рахунок введення активованого фактора згортання (тромбіну). Дослідження гемостазіологічного стану плазми крові включало визначення протромбінового часу за Квіком, протромбінового індексу, активованого часткового тромбопластинового часу, фібриногену А та фібрин-мономерного комплексу.

Результати. Проведений статистичний аналіз підтверджує активізацію згортальної системи крові.

Висновок. Доведено взаємозв'язок флеботромбозу з неопластичною інтоксикацією та виражених змін у системах згортання крові.

КЛючОВІ СЛОВА: експериментальна хронічна неопластична інтоксикація; ендогенна інтоксикація; згортальна система крові; фібриноген; плазма крові.

Робота виконана в контексті науково-дослідної роботи кафедри хірургії № 1 з урологією та малоінвазивною хірургією імені Л. Я. Ковальчука Тернопільського національного медичного університету імені І. Я. Горбачевського, м. Тернопіль, «Розробка нових відкритих і лапароскопічних операційних втручань при лікуванні захворювань органів черевної порожнини на принципах мультимодальної програми» "Fast track surgery", № держреєстрації 01190002805.

Вступ. Складна біологічна система, яка забезпечує стабільність рідкого стану крові, а в умовах порушення цілісності судин зупиняє кровотечу, називається гемостазом. Різноманіття завдань, що стоять перед цією системою, зумовило її високу складність. Гемостаз забезпечується декількома взаємопов'язаними структурно-функціональними компонентами, до яких належать: коагулянтна ланка (плазмові фактори); антикоагулянтна ланка (фізіологічні антикоагулянти); фібринолітична система; клітинні фактори формених елементів крові; фактори згортання і фібринолізу судинної стінки та навколишніх тканин. Взаємодія цих компонентів у системі гемостазу знаходиться в межах фізіологічних коливань між гіпо- та гіперкоагуляцією.

Фібриноген - один з найбільш гетерогенних білків плазми крові, структурні компоненти якого диференціюються й після біосинтезу різноманітними способами. Це результат трьох причин: альтернативного процесингу під час біосинтезу, посттрансляційної модифікації амінокислотних залишків та протеолітичної деградації $[1,2]$. У наш час інтенсивно розвиваються дослідження в сфері саме клітинного гемостазу. Концепція згортання крові $\epsilon$ загальновизнаною та фізіологічно обґрунтованою. Основну роль у реалізації клітинного згортання крові відіграють тромбоцити та ендотеліальні клітини. В умоваx in vivo клітинний та плазмовий гемостаз пов'язані між собою та $\epsilon$ єдиною системою. Ендогенна інтоксикація, як процес накопичення у тканинах та біологічних рідинах надлишкової концентрації токсичних речовин, сприяє погіршенню реологічних властивостей крові та значною мірою впливає на утворення тромбів та розвиток гіпоксії тканин.

Проблема оптимізації протоколів лікування та схем полегшення стану організму при різноманітних порушеннях гомеостатичної рівноваги $\epsilon$ однією з найактуальніших. Венозні тромбози виникають у різноманітних клінічних ситуаціях та ускладнюють безліч захворювань. Це пов'язано з неВпинним ростом частоти тромбозу глибоких вен (ТГВ), яка досягає 160 випадків на 100000 населення на рік. Такий високий показник обумовлений змінами життя сучасної людини (гіподинамія, характер харчування, надлишкова вага тіла тощо), збільшенням травматизму та виникненням спадкових або набутих порушень системи гемостазу, 
Огляди літератури, оригінальні дослідження, погляд на проблему, випадок з практики, короткі повідомлення поширеністю онкологічних захворювань, неконтрольованим прийомом гормональних препаратів тощо [3]. Результати лікування гострого флеботромбозу та його наслідків не можна вважати задовільними [3, 5]. Вивчення в експерименті біохімічних та реологічних показників крові за умов хронічної неопластичної інтоксикації, а також дії цитостатичних препаратів, дасть змогу уточнити і доповнити клінічну важливість проблеми тромбоемболічних ускладнень.

Мета - оцінити стан згортальної системи плазми крові щурів за умов хронічної неопластичної інтоксикації та експериментального флеботромбозу.

Матеріал і методи дослідження. Експеримент виконано на 25 статевозрілих нелінійних щурах-самцях масою 170-180 г. Тварин утримували на збалансованому стандартному раціоні віварію Тернопільського національного медичного університету імені І. Я. Горбачевського МОЗ України. Моделювали патологічні процеси і виводили щурів 3 досліду згідно з принципами біоетики, правилами належної лабораторної практики (GLP), а також етичними нормами, викладеними в положеннях Європейської конвенції про захист хребетних тварин, які використовуються для дослідних та інших наукових цілей, та відповідно до Науково-практичних рекомендацій з утримання лабораторних тварин та роботи з ними [4].

Хронічну неопластичну інтоксикацію моделювали шляхом введення несиметричного 1,2-диметилгідразин гідрохлориду (ДМГ) (фірми «SIGMAAL DRICH CHE MIE», виробництва Японії, серії D161802), попередньо розведеного ізотонічним розчином натрію хлориду. Канцероген вводили підшкірно в міжлопаткову ділянку в дозі 7,2 мг/кг (з розрахунку на діючу речовину) 1 раз на тиждень упродовж 30 днів, відповідно до маси тварини - 3 розрахунку 0,1 мл розчину ДМГ на 10 г маси тіла щура. Летальність становила 8 \%. Протягом 30-го дня експерименту загинули 2 тварини. Контролем для основної експериментальної групи тварин, яким вводили ДМГ, були 12 щурів, яким щотижня підшкірно вводили 0,1 мл фізіологічного розчину на 10 г маси тіла. Дослідження гемостазіологічного стану плазми крові включало визначення протромбінового часу за Квіком, протромбінового індексу, активованого часткового тромбопластинового часу, фібриногену А та розчинного фібрин-мономерного комплексу згідно з інструкцією до реактивів фірми «RE NAM» (Німеччина).

Результати й обговорення. Проведені дослідження виявили зв'язок флеботромбозу з неопластичною інтоксикацією, які в динаміці призводять до виражених змін у системах згортання та фібринолізу крові. Отримані дані наведені в таблиці 1.

Установлено, що час згортання крові у щурів дослідної групи перевищував контрольні дані на 74,6 \% (Р<0,001). Впродовж усіх 30 днів експерименту спостерігалось тільки його зростання та досягнення 129,6 \% вище вихідних даних.

Таблиця 1. Динаміка показників коагуляції венозної крові при неопластичній інтоксикації на фоні

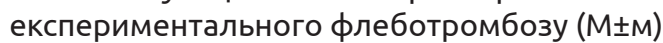

\begin{tabular}{|c|c|c|c|c|c|c|c|}
\hline \multirow{2}{*}{ Показники } & \multirow{2}{*}{$\begin{array}{c}\text { Гру- } \\
\text { па } \\
\end{array}$} & \multirow{2}{*}{ Вихідні дані } & \multicolumn{5}{|c|}{ Етапи спостереження (доба) } \\
\hline & & & 1 & 5 & 10 & 15 & 30 \\
\hline \multirow[t]{2}{*}{$\begin{array}{l}\text { Згортання за } \\
\text { Лі-Уайтом, с }\end{array}$} & 1 & $293,83 \pm 7,43$ & $\begin{array}{c}209,00 \pm \\
7,50 * *\end{array}$ & $\begin{array}{c}228,80 \pm \\
9,60 * *\end{array}$ & $\begin{array}{c}217,20 \pm \\
5,50 * *\end{array}$ & $\begin{array}{l}205,60 \pm \\
5,40 * * *\end{array}$ & $\begin{array}{c}268,40 \pm \\
10,20\end{array}$ \\
\hline & II & $293,83 \pm 7,43$ & $\begin{array}{c}207,80 \pm \\
6,50 \# \# \# * *\end{array}$ & $\begin{array}{c}210,00 \pm \\
8,50 \# \# \# * * *\end{array}$ & $\begin{array}{c}211,70 \pm \\
13,80 \# \# \# * * *\end{array}$ & $\begin{array}{c}195,00 \pm \\
13,30 \# \# \# * * *\end{array}$ & $\begin{array}{l}248,80 \pm \\
11,40 \# \#\end{array}$ \\
\hline \multirow[t]{2}{*}{$\begin{array}{l}\text { Час рекальци- } \\
\text { фікації, с }\end{array}$} & 1 & $124,71 \pm 4,70$ & $\begin{array}{c}111,42 \pm \\
6,20\end{array}$ & $\begin{array}{l}86,10 \pm \\
3,60 * *\end{array}$ & $71,15 \pm 4,30 * *$ & $\begin{array}{l}56,20 \pm \\
2,90 * * *\end{array}$ & $\begin{array}{c}104,90 \pm \\
6,30 *\end{array}$ \\
\hline & II & $124,71 \pm 4,70$ & $\begin{array}{c}108,20 \pm \\
1,52 \# \# \# * * *\end{array}$ & $\begin{array}{c}75,10 \pm \\
8,70 \# \# \# * * *\end{array}$ & $\begin{array}{c}65,30 \pm \\
7,26 \# \# \# * * * \\
\end{array}$ & $\begin{array}{c}48,10 \pm \\
11,20 \# \# \# * * *\end{array}$ & $\begin{array}{c}85,40 \pm \\
10,80 \# \# * * \\
\end{array}$ \\
\hline \multirow{2}{*}{$\begin{array}{l}\text { Протром- } \\
\text { біновий час, с }\end{array}$} & 1 & $19,4 \pm 0,8$ & $17,6 \pm 0,7$ & $14,7 \pm 0,7^{*}$ & $12,4 \pm 0,6^{* *}$ & $10,2 \pm 0,3 * * *$ & $16,7 \pm 1,1$ \\
\hline & II & $19,4 \pm 0,8$ & $\begin{array}{c}15,3 \pm \\
1,1 \# \# \# * *\end{array}$ & $\begin{array}{c}12,1 \pm \\
1,2 \# \# \# * * *\end{array}$ & $\begin{array}{c}9,5 \pm \\
1,1 \# \# \# * * *\end{array}$ & $\begin{array}{c}8,6 \pm \\
1,2 \# \# \# * * *\end{array}$ & $11,2 \pm 1,9$ \\
\hline \multirow[t]{2}{*}{ АЧТЧ, С } & 1 & $91,97 \pm 3,56$ & $\begin{array}{l}62,10 \pm \\
3,40 * *\end{array}$ & $\begin{array}{c}73,30 \pm \\
2,51 *\end{array}$ & $\begin{array}{l}62,90 \pm \\
3,60 * *\end{array}$ & $\begin{array}{l}52,60 \pm \\
2,60 * * *\end{array}$ & $86,40 \pm 5,40$ \\
\hline & II & $91,97 \pm 3,56$ & $\begin{array}{l}58,13 \pm \\
1,06 * *\end{array}$ & $\begin{array}{l}65,3 \pm \\
0,70 *\end{array}$ & $\begin{array}{c}54,51 \pm \\
1,47 \# \# \# *\end{array}$ & $\begin{array}{c}48,05 \pm \\
3,50 \# \# \# * *\end{array}$ & $78,70 \pm 5,90$ \\
\hline \multirow[t]{2}{*}{$\begin{array}{l}\text { Фібриноген, } \\
\text { г/л }\end{array}$} & 1 & $3,44 \pm 0,15$ & $\begin{array}{l}3,85 \pm \\
0,04 *\end{array}$ & $\begin{array}{l}4,41 \pm \\
0,04 * *\end{array}$ & $\begin{array}{l}4,64 \pm \\
0,02 * *\end{array}$ & $\begin{array}{c}4,96 \pm \\
0,09 * * *\end{array}$ & $4,03 \pm 0,52$ \\
\hline & II & $3,44 \pm 0,15$ & $\begin{array}{c}3,91 \pm \\
0,12 \# \#\end{array}$ & $\begin{array}{c}4,95 \pm \\
0,19 \# \# \# *\end{array}$ & $\begin{array}{c}5,06 \pm \\
0,14 \# \# \# * *\end{array}$ & $\begin{array}{c}5,25 \pm \\
0,09 \# \# \# * *\end{array}$ & $4,6 \pm 0,80$ \\
\hline
\end{tabular}

Примітки: 1. Достовірність змін по відношенню до вихідного рівня: *** - при р<0,001; ** - при р<0,01; * при р<0,05.

2. Достовірність різниці між даними контрольної і експериментальної груп: \#\#\# - при Р<0,001; \#\# - при P<0,01; \# - при Р<0,05. 
Огляди літератури, оригінальні дослідження, погляд на проблему, випадок з практики, короткі повідомлення

Розвинені на фоні експерименту гіперкоагуляційні порушення в крові підтверджують отримані нами результати дослідження часу рекальцифікації, протромбінового часу і АЧТЧ. Час рекальцифікації і протромбіновий час уже до кінця першої доби був нижче контрольного.

Максимальне зменшення часу тестів спостерігалося до 10-15 доби. АЧТЧ у плазмі крові до 10-ї і 15-ї діб зменшувався на 19,1% і 36,0% (P<0,001), порівняно з контрольним рівнем. У віддалений період спостереження час рекальцифікації в плазмі залишався меншим від початкового на 64,7 \% $(P<0,01)$. Протромбіновий час і АЧТЧ до 30 доби експерименту відповідали даним у контрольній групі тварин.

\section{ЛITЕРАТУРА}

1. Davie E. W. Waterfall sequence for intrinsic blood clotting / E. W. Davie, O. D. Ratnoff // Science. - 1964. Vol. 145 (3638). - P. 1310-1312.

2. Owen C. A. A history of blood coagulation / C. A. Owen, W. L. Nichols, E. J. W. Bowie // Mayo Foundation for Medical Education and Research. - 2001. - P. 355.

3. Пан В. И. Острый эмбологенный флеботром$6 о з$ в системе нижней полой вены в свете отдаленных результатов / В. И. Пан [и др.] // Регионарное кровообращение и микроциркуляция. - 2017. - № 16 (2). с. $50-53$.

\section{REFERENCES}

1. Davie, E.W., \& Ratnoff, O.D. (1964). Waterfall sequence for intrinsic blood clotting. Science, 145(3638), 1310-1312.

2. Owen C.A., Nichols W.L., \& Bowie E. J. W. (2001). A history of blood coagulation. Mayo Foundation for Medical Education and Research.

3. Pan, V.I., Gordeev, N.A., Mjasnikova, M.O., \& Morozov, V.P. (2017). Ostryi jembologennyi flebotromboz v sisteme nizhnei poloi veny $v$ svete otdalennyh rezultatov [Acute embologenous phlebothrombosis in the inferior vena cava system in the light of long-term results]. Regionarnoe krovoobrashhenie i mikrocirkuljacija-Regional Blood Circulation and Microcirculation, 16 (2), 50-53 [ in Russian].
У наших дослідженнях також змінювалася концентрація фібриногену в плазмі крові. Відмічено його наростання у щурів дослідної групи на 45,6 \% - 59,7 \% вище контролю в плазмі $(P<0,001)$.

Висновки. 1. Неопластична інтоксикація $\epsilon$ незалежним предиктором розвитку гемостазіологічних порушень з підвищенням згортальної активності крові.

2. При експериментальному флеботромбозі у сироватці щурів на тлі хронічної неопластичної інтоксикації спостерігається тенденція до погіршення реологічних властивостей крові, що корелює із вірогідним зменшенням часу рекальцифікації, протромбінового часу та активованого часткового тромбінового часу із максимальною негативною динамікою на 30-й день експерименту.

4. Кожемякін Ю. М. Науково-практичні рекомендації з утримання лабораторних тварин та роботи 3 ними / Ю. М. Кожемякін, О. С. Хромов, М. А. Філоненко, Г. А. Сайфетдінова. - Київ : Авіцена, 2002. - 156 с.

5. Lugovskoi E. V. A neoantigenic determinant in Ddimer fragment of fibrinogen and fibrin / E. V. Lugovskoi, I. N. Kolesnicova // Tromb. Res. - 2002. - Vol. 107, No. 3. P. 151-156.

6. Wessler S. Biological assay of a thrombosis inducing activity in human serum / S. Wessler, S. M. Reimer, M. C. Sheps // J. Appl. Physiol. - 1959. - Vol. 14. - P. 943-946.

\title{
СОСТОЯНИЕ СВЕРТЫВАЮЩЕЙ СИСТЕМЫ ПЛАЗМЫ КРОВИ ПРИ НЕОПЛАСТИЧЕСКИХ ИНТОКСИКАЦИЯХ НА ФОНЕ ЭКСПЕРИМЕНТАЛЬНОГО ФЛЕБОТРОМБОЗА
}

\author{
๑П. Я. Боднар, И. Н. Клищ, Я. Я. Боднар, Т. В. Боднар, Ю. В. Сорока
}

Тернопольский национальный медицинский университет имени И. Я. Горбачевского МОЗ Украины

РЕЗЮМЕ. Ухудшение реологических свойств крови в значительной степени влияет на образование тромбов и развитие гипоксии тканей. Наиболее часто нарушения проявляются именно на конечном этапе фибрино- и тромбиногенеза. Примерами могут служить ДВС-синдром, ишемическая болезнь сердца, инфаркт миокарда, 
Огляди літератури, оригінальні дослідження, погляд на проблему, випадок з практики, короткі повідомлення инсульт головного мозга, тромбоз глубоких вен и тромбоэмболия легочной артерии (ТЭЛА). Изучение механизмов флеботромбоза при неопластической интоксикации позволит предотвращать осложнения и улучшит лечение многих видов патологий.

Цель - изучение состояния и морфофункциональных изменений свертывающей системы плазмы крови крыс при моделировании неопластической интоксикации на фоне экспериментального флеботромбоза с последующим проведением статистического анализа для предупреждения негативных изменений в системе гемостаза.

Материал и методы. Эксперимент выполнен на 25 половозрелых нелинейных крысах. Хроническую неопластическую интоксикацию моделировали путем введения несимметричного 1,2-диметилгидразина гидрохлорида (ДМГ) подкожно в межлопаточную область в дозе 7,2 мг/кг 1 раз в неделю в течение 30-ти недель, согласно массы животного - из расчета 0,1 мл ДМГ на 10 г массы тела крысы. Тромбоз глубоких вен тазовой конечности моделировали по методу S. Wessler и соавт. (1959): сочетание венозного застоя (лигирование вены) и гиперкоагуляции за счет введения активированного фактора свертывания (тромбина). Исследование гемостазиологического состояния плазмы крови включало определение ПВ по Квику, протромбинового индекса, активированного частичного тромбопластинового времени, фибриногена А и фибрин-мономерного комплекса.

Результаты. Проведенный статистический анализ подтверждает активизацию свертывающей системы крови.

Заключение. Доказана взаимосвязь флеботромбоза с неопластической интоксикацией и выраженных изменений в системах свертывания крови.

КЛЮЧЕВЫЕ СЛОВА: экспериментальная хроническая неопластическая интоксикация; эндогенная интоксикация; свёртывающая система крови; фибриноген; плазма крови; фибринолиз.

\section{STATE OF THE BLOOD PLASMA COAGULATION SYSTEM IN NEOPLASTIC INTOXICATION AGAINST ON THE BACKGROUND OF EXPERIMENTAL PHLEBOTHROMBOSIS

\author{
OP. Ya. Bodnar, I. M. Klishch, Ya. Ya. Bodnar, T. V. Bodnar, Yu. V. Soroka \\ I. Horbachevsky Ternopil National Medical University
}

SUMMARY. Deterioration of blood rheological properties greatly affects the formation of thrombi and the development of tissue hypoxia. It is the end-stage fibrinopeptide and thrombinogenesis that are most frequently clinically affected. Examples are DIC, coronary heart disease, myocardial infarction, cerebral stroke, deep vein thrombosis and pulmonary embolism (TELA). The study of phlebothrombosis mechanisms in neoplastic intoxications will allow to prevent complications and improve treatment of many types of pathologies.

The aim - to study the state and morphofunctional changes of the rat blood plasma coagulation system in the modeling of neoplastic intoxication against the background of experimental phlebothrombosis followed by statistical analysis to prevent adverse changes in the hemostasis system.

Material and Methods. The experiment was carried out on 25 sexually mature nonlinear rats. Chronic neoplastic intoxication was modeled by injection of asymmetric 1.2-dimethylhydrazine hydrochloride (DMH) subcutaneously in interscapular region in dose $7 / 2 \mathrm{mg} / \mathrm{kg}$ once per week during 30 weeks according to animal weight $-0.1 \mathrm{ml} \mathrm{DMH} \mathrm{per} 10 \mathrm{~g}$ of rat body weight. Deep vein thrombosis of the pelvic limb was modeled by S. Wessler (1959): a combination of venous congestion (vein ligation) and hypercoagulation, due to the introduction of activated coagulation factor (thrombin). Hemostasis testing of blood plasma included determination of PT according to Quick, prothrombin index, activated partial thromboplastin time, fibrinogen A and fibrin monomer complex.

Results. The relationship between phlebothrombosis and neoplastic intoxication and marked changes in blood coagulation systems has been proven.

Conclusions. The performed statistical analysis confirms the activation of the blood coagulation system.

KEY WORDS: experimental chronic neoplastic intoxication; endogenous intoxication; blood coagulation system fibrinogen: blood plasma fibrinolysis.

Отримано 22.04.2021 